\title{
Anglo-Portuguese relations on the Western Front: the Portuguese Expeditionary Corps and the British High Command (part I)
}

\section{Filipe Ribeiro de Meneses}

To cite this article: Filipe Ribeiro de Meneses (2017) Anglo-Portuguese relations on the Western Front: the Portuguese Expeditionary Corps and the British High Command (part I), First World War Studies, 8:2-3, 173-187, DOI: 10.1080/19475020.2017.1393345

To link to this article: https://doi.org/10.1080/19475020.2017.1393345

\section{Published online: 26 Oct 2017.}

Submit your article to this journal ๘

山ll Article views: 105

Q View related articles ¿

View Crossmark data \lceil 


\title{
Anglo-Portuguese relations on the Western Front: the Portuguese Expeditionary Corps and the British High Command (part I)
}

\author{
Filipe Ribeiro de Meneses \\ Department of History, Maynooth University, Maynooth, Ireland
}

\begin{abstract}
The Portuguese Expeditionary Corps [C.E.P.] was the centrepiece of Portugal's intervention in the First World War. It was despatched to France in order to secure international plaudits for Portugal and its young republican regime, in place since October 1910. This political objective required the C.E.P. to be as independent a force as possible. Unfortunately, the C.E.P. failed to impress its senior partner, the British Army, whose High Command soon lost faith in it, applying pressure to the British Government either to remove the C.E.P. altogether or to limit, as far as possible, the Portuguese presence in the trenches. Despite this, in November of 1917 a 'Portuguese Sector' was constituted in Flanders, with the two Portuguese divisions fighting side by side. This article investigates the nature of the misgivings between the two armies and considers why, in such a charged atmosphere, the British High Command was forced to give way.
\end{abstract}

\section{ARTICLE HISTORY}

Received 23 November 2016 Accepted 13 October 2017

\section{KEYWORDS}

Portugal; Great Britain; Western Front; command; shipping

On 8 September 1917 Lord Derby, British Secretary of State for War, wrote to his Portuguese counterpart, José Maria Norton de Matos. Winter was approaching, he reminded Norton de Matos, as a result of which Sir Douglas Haig was increasingly concerned about the Portuguese troops under his command, who would soon number two complete infantry divisions and supporting forces. Needless casualties, it was predicted, would result from their prolonged permanence in the trenches. Haig had thus proposed that one Portuguese division remained - as it had been for some time - a part of a British army corps, under the tactical authority of the corps commander, while the other served as a reserve and training force, its units periodically replacing those of the combat division. General Tamagnini de Abreu, the commander of the Portuguese Expeditionary Corps [Corpo Expedicionário Português, C.E.P.], would stay on in France as an Inspector General of the force. Derby then had recourse to a historical precedent in order to justify his next suggestion, more difficult to swallow. During the Peninsular War British officers had served in the Portuguese army, 'to the great advantage of both countries'. Derby suggested reinstating this practice, inserting a number of British officers into each Portuguese battalion or similarly sized unit; they could keep an eye on the troops' instruction when not in the trenches, and, if necessary, assume 
command in battle. The practical details could be worked out later; all that was needed now was a broad agreement. ${ }^{1}$

Upon receiving the letter, a shocked Norton de Matos immediately consulted with General N.W. Barnardiston, who for over a year had been serving as the head of the British Military Mission in Lisbon. The Minister inquired if there were any hidden motives for Derby's letter, which had arrived out of the blue. Barnardiston replied that he did not know of any, adding that a unit so weakened by illness could not be expected to repulse a German attack and that Derby's plan was a way of guaranteeing the presence of a Portuguese force in the front lines, with reinforcements close at hand. He did, however, admit without any further elaboration that distrust of some Portuguese officers might have contributed to the plan. For the benefit of General Sir R.D. Whigham, Deputy Chief of the Imperial General Staff, Barnardiston then explained that 'the principle adopted during the Peninsular War has left most unpleasant memories in Portugal'; according to Norton de Matos, reproducing such a step would lead to 'violent opposition'. The timing, finally, could not be worse, since 'the centenary of the so-called 'martyrdom' of Portuguese 'patriot', General Gomes Freire de Andrade, who was executed by Beresford for conspiracy in 1817 is just about to be celebrated.' Setting Barnardiston's questionable use of quotation marks aside, the matter was indeed delicate. William Carr Beresford, the Anglo-Irish commander of the Portuguese army during and after the Peninsular War, had acted in his capacity as leader of the Regency governing Portugal in the wake of the Napoleonic wars; General Freire de Andrade, for his part, had plotted to overthrow that very Regency, establish a liberal regime, and demand the return to Portugal of the country's King, John VI, in Brazil since 1808.

What is more, Freire de Andrade, a celebrated officer, had been one of the commanders of the Portuguese Legion, a military unit integrated into Napoleon's Grande Armée and therefore serving his country's (and Britain's) enemy. Its men were very much on Norton de Matos' mind when, on 1 October, he replied to Derby's letter. He rejected all of the latter's proposals, 'with the rude frankness of a soldier.' ${ }^{3}$ Any alteration to the Convention between the two countries governing the existence of the C.E.P. would deeply wound national sentiment; everyone understood and appreciated the instruction received from, as well as the example set by, British officers, but Portugal could go no further in accommodating British wishes. Norton de Matos then informed Derby that Portuguese soldiers could cope with winter temperatures; they had, after all, been singled out by Napoleon as an example to the rest of the Grande Armée during the retreat from Moscow - a not very subtle reminder that there was more to Portugal's military tradition than cooperation with Britain. What to the British Army was a clear lesson derived from its previous large-scale campaign on the continent, to the Portuguese - especially the republicans now in power - was a source of shame, a reminder of their country's historical decline. Less than three weeks after writing this letter, at a moment when both the President of the Republic, Bernardino Machado, and the Prime Minister, Afonso Costa, were visiting the front lines in France, Norton de Matos led the Freire de Andrade centenary celebrations in the town of Oeiras. Three other ministers were present, as were a deputation from Lisbon's municipal chamber, delegations from all the military units in the Lisbon garrison, police forces, and local schools; according to the press, only the incessant rain kept a larger crowd away. A military band played the national anthem as Norton de Matos unveiled a plaque in the already existing monument to Freire de Andrade, which read, 'To Gomes Freire de Andrade. First centenary of this death, 18-10-1917. A homage by the Portuguese people.4 
This short exchange between Derby and Norton de Matos suggests that relations between the British and Portuguese armies were tense; in reality, they were considerably worse than that, even if not all concerned realized this. The aim of this article is to consider the evolution of the relations between the two army's commands, which at times were frankly poor and which led to some very questionable decisions being taken. These decisions resulted in a paradoxical situation: while the British High Command considered the C.E.P. a weak point in its lines, which it would have preferred to remove, its actions served only to weaken the formation even as it remained in place. Combined with changing circumstances in Portugal, British actions made the C.E.P.s long-term survival as a fighting force close to impossible. ${ }^{5}$

Derby's letter was written on the basis of a much harsher document produced some days earlier by Sir Douglas Haig. ${ }^{6}$ As far as Haig was concerned, it was simply unacceptable to hand over a whole army corps front to the C.E.P.: a single division was already proving to be the source of constant worry, and casualties would naturally increase in the winter. The ideal outcome was for all the Portuguese to go home, or to some other battlefield; but should political considerations render this impossible, then, Haig explained, it was time to apply the lessons of the Peninsular War: British officers should take charge of the troops' training and of their combat operations. The soldiers were salvageable, but the officers were not; the time had come to admit this fact and act accordingly. And if this too proved impossible to enforce for political reasons, then at the very least only one division should be at the front with the other in the rear, in accordance with the scheme later proposed by Derby:

I desire to make it clear however that, even under such a system, the security of any portion of the line held by these troops must always cause grave misgiving and the consequences might be serious if they were attacked and gave way.

Haig's suggestions were themselves borrowed from recent reports drawn up by Generals Sir Henry Horne, commander of the British First Army, and Sir Richard Haking, commander of XI Army Corps, comprised in part of the Portuguese First Division. Haking's extensive document dated from mid-August. In it he expressed his concern over the limited influence British officers enjoyed over the C.E.P., contact having been limited to a short period in the trenches under British supervision. Wise advice had since been ignored,

with the result that the troops themselves have received a sort of veneer of instruction, which has been poured over them and is likely to wear off, but they have never been properly nourished and built up with it. ${ }^{7}$

Hence, Haking went on, the First Division had been kept under a tight lead. There had been improvements, notably regarding the maintenance of defensive positions, but these had only come about thanks to his own constant and direct intervention. This required weekly meetings with Tamagnini, General Gomes da Costa (commander of the First Division) and brigade commanders, examining their activity in detail - but the Portuguese had revealed themselves to be masters in the art of dodging responsibility for their errors. The consequences were felt in all aspects of the C.E.P.s life, not least the troops' morale. If attacked, the First Division would give way; that was Haking's estimation.

The issue of poor morale was especially troubling for Haking, who ascribed it to many different causes: the opinion, voiced so often that it had become an axiom, that the Portuguese Army was not suited for trench warfare, (a ploy, he believed, to avoid taking responsibility for mistakes, but also to eschew the preservation of an offensive spirit through regular raids against enemy positions); ignorance - real or feigned - of the reasons for Portugal's 
belligerence and the C.E.P.s presence in France; the political situation in Portugal, which generated friction and generated pointless arguments which in turn contributed nothing to the defeat of the enemy; and constant clashes with French civilians, used to dealing with the better-off British soldiers:

They have no money to spend, they are dirty in their habits, they are not above stealing things out of the fields, and their attitude towards the women is not always correct. They have one good point, they very rarely get drunk.

Morale was further depressed by the approaching winter, during which many soldiers expected to die of exposure. The C.E.P.s administrative and logistical shortcomings meant that its food was poor, as were its uniforms. Soldiers also complained of their British-style rations, heavy on meat, cheese, and pickles: 'They want to fill their stomach every day with vegetables as they do at home.' The solution was to suspend parts of the Convention governing relations between the two armies, allowing British officers to take command of all the training centres in France where Portuguese soldiers made the transition to trench warfare. Portuguese soldiers were 'not at all bad', and deserved better officers; this was one way of providing them.

Tellingly, Haking also requested the removal of Major Roberto Baptista, the C.E.P.s Chief of Staff, who seemed to belong to a 'secret political society'; this step would strengthen the hand of both Tamagnini and Gomes da Costa, with whom Haking found he could work. It was thanks to Baptista's misinformation, Haking believed, that politicians in Lisbon had a false impression of the C.E.P. and its merits (in this he was right, see below). Lastly, Haking suggested that the recently arrived Second Division be used as a depot for the First, whose integration into a British army corps would be made permanent. Curiously, Haking's report was not the origin of this idea. In a letter addressed simply to Mackenzie, ${ }^{8}$ the author, most probably Lieutenant-Colonel Charles Ker, head of the British Mission to the C.E.P., explained that he was passing on the views of General Gomes da Costa, and asking to have these relayed to XI Corps. Gomes da Costa was worried by the lack of reserves within his formation; 80 officers, 400 NCOs and 1500 soldiers had still to arrive - but now there was talk of a Second Division, before the First had been completed. He had informed Tamagnini that, in his opinion, Lisbon would never send enough men and officers to keep two divisions in the front lines, as a result of which the Second Division should be cannibalized in order to keep up the First's strength, serving only as a training force. The plan naturally did not please Tamagnini, who understood it as part of a strategy to deny him the command he had been so patiently awaiting. This document's importance lies in the similarity it reveals between the points of view of the British High Command and General Gomes da Costa, who in British eyes was the C.E.P.s most talented senior officer. The letter's contents were confirmed by Tamagnini, who wrote, in a diary entry dated 8 August,

I concluded from what has been happening and by reading between the lines of my conference with Freiria [Chief of Staff of the 1st Division]: 1) that Gomes da Costa wanted, under the pretext of needing reinforcements, to absorb the 2nd Division, which I have always opposed, because otherwise the Corps would never be formed [...] 2) that since he did not get his way, despite writing various notes on the subject, he reached out to the Commander of XI Corps to help him; 3) he thought that if we had only one division, he would be left in charge. I was very saddened by these conclusions, because they reveal what happens to those gripped by ambition and deviousness. ${ }^{9}$ 
A week after receiving Haking's report, Horne summarized it for Haig's benefit. ${ }^{10}$ Horne showed himself to be in complete agreement with Haking. The creation of a Portuguese army corps, responsible for a long stretch of the front, would be a mistake; so too would be keeping the Portuguese in the front lines during the winter. Out of respect for Portugal's - and Tamagnini's - dignity, Horne now repeated the suggestion that the Second Division become a training force, its brigades being used to allow the First Division's fourth brigades to rest.

These reports, travelling up the military hierarchy from Haking to Derby, were produced at a crucial moment in the C.E.P.s history, when it was about to be transformed from an ungainly formation - an infantry division ${ }^{11}$ with supporting units answerable both to the British army corps to which it belonged and to its own corps command - into a full-blown army corps. For the Portuguese Government, this was an essential step, desirous as it was of establishing, for domestic and international consumption, a Portuguese sector on the Western Front that might be presented as the notional equivalent - even if much smaller - of the British and French sectors. ${ }^{12}$ This, of course, was nothing short of a hoax, since even an army corps would be dependent on a larger formation (in this case Horne's First Army) and the C.E.P. was completely reliant on the British Army for almost all of its supplies (the exceptions being wine and coffee, which the Portuguese Government had agreed to supply). It was also dependent - and this was its Achilles' heel - on British shipping for the transportation of troops from Portugal to France, be it as part of an expansion of the force, be it as part of its normal reinforcement. ${ }^{13}$ But for the British generals responsible for the collaboration with the Portuguese, this was simply unacceptable, for reasons we will examine below.

That a Second Division was in the offing was not a surprise. Even before the First left Lisbon Barnardiston had already been asked by London if another was to follow. ${ }^{14}$ Barnardiston's reply, delayed as a result of a significant coup attempt launched on 13 December 1916, was equivocal: 'It depends on a great many things [...] it may be that having sent one large division to the Front people may think that they have done enough'; in any case, keeping up the initial force's strength would require monthly reinforcements of some 3-4000 soldiers per month, a considerable burden for Portugal. ${ }^{15}$ The origins of the actual decision to transform the C.E.P. into an army corps are not very clear. In his recently published memoirs, Tamagnini noted that it was almost an afterthought. Early in February 1917, before his departure to France, at a meeting in the presence of the C.E.P.s Chief of Staff and its artillery commander, in the Ministry of War, it was stated that the British would welcome the inclusion of heavy artillery in the C.E.P. Since a lone division did not require heavy artillery, the decision was taken to up the expeditionary force to two divisions, in order to justify the despatch of heavy artillery as well. ${ }^{16}$ But João Chagas, Portugal's minister at Paris, noted in his diary that Baptista had set off for Lisbon in advance of this meeting with every intention of raising the issue of the army corps, since 'the support of one division is not sufficient to give Portugal an independent situation and worthwhile position'. And Norton de Matos would claim in February 1917 to have 'studied carefully the military, economic and financial possibilities of the country', as a result of which he had concluded that Portugal could afford to send immediately two divisions, in order to form an army corps. ${ }^{17}$ Events gathered pace, so that the War Office informed Haig, on 6 March, that an arrangement had been entered into with the Portuguese Government for this expansion. The transformation would be carried out by sending two groups of $75 \mathrm{~mm}$ guns, 1 medium trench mortar battery, 10 batteries of heavy and siege artillery and 6 infantry battalions - 12,000 officers and 
men in total. Monthly reinforcements would be increased to 5000 per month, and it was hoped that the embarkation of these supplementary troops would occur seamlessly after the despatch of the First Division. ${ }^{18}$

On 3 April, however, Haig was informed that the British Government had declared itself unable to provide the shipping necessary to transport the additional forces required for the C.E.P's transformation to an army corps. ${ }^{19}$ There is no extant proof of that the Admiralty was responding to the High Command's concerns in this decision; in fact, Barnardiston had on occasion complained to the Portuguese Government about the under-utilization of the ships supplied by the Admiralty for the transport of troops. Just on 29 March, Barnardiston had informed Norton de Matos that the convoy of four ships which had departed a week earlier could have transported nearly 1500 men more, had the organization on the Portuguese side not been deficient. ${ }^{20}$ This suggests the possibility of the hard-pressed Admiralty going on a solo run in relation to the C.E.P. The Portuguese reaction to the withdrawal of the ships was immediate, with contact at the highest levels leading to a discussion of the matter at Cabinet level in London:

The Portuguese Minister for War has pointed out that his proposal to convert the Expeditionary Force into an army corps had been fully discussed with General Barnardiston, and that to suspend the operation now would create material losses and a bad moral effect. The additional transport required involves only two extra voyages of the ships now employed. ${ }^{21}$

This might have been true in terms of constituting the Second Division, but not in terms of reinforcements. For Afonso Costa, recently appointed prime minister, one possible culprit for this decision was Jan Smuts, who had left East Africa to take up a seat in the British War Cabinet, and who had not been impressed by the Portuguese military performance in the colonies. In any case it was important to resolve this issue, and so Norton de Matos was despatched to London. ${ }^{22}$ Along the way he met Haig, who thought him 'quite an energetic and keen little man' and pressed him to dismiss Baptista, identified in countless reports as the source of the delays that plagued the C.E.P.s preparation. ${ }^{23}$ Norton de Matos did not remove this officer (in fact he brought him to London), who played a crucial role in ensuring respect for the Convention as part of a wider struggle to ensure respect for Portuguese prerogatives. On 22 May a first meeting between the two delegations took place at the War Office; the British were led by Lord Robert Cecil, Parliamentary Under Secretary for Foreign Affairs, and Sir John Jellicoe, First Sea Lord. Cecil claimed that it would be difficult to find the merchant ships needed to satisfy Portuguese wishes; Jellicoe, for his part, promised to try to find two destroyers to escort them, adding that it would be impossible to provide any more. Barnardiston, who was present, noted of the Portuguese that they 'were of course far from satisfied and evidently did not intend to let the matter rest there, but the Minister [Teixeira Gomes] said to M. de Matos afterwards that he had known negotiations terminate successfully which had begun with less prospects of success. ${ }^{24}$

After this meeting, a long pause ensued, Norton de Matos awaiting a definitive response from his interlocutors. The matter was discussed at the War Cabinet on 31 May, Derby suggesting that Norton de Matos' desire to meet David Lloyd George be exploited in order to secure permission for the British to recruit 20,000 carriers in Mozambique, to which the Portuguese had so far been opposed. ${ }^{25}$ On 2 June, Norton de Matos' situation was discussed by the Portuguese cabinet. An impasse had developed; since the Portuguese did not seem willing to place more ex-German ships at London's disposal, the British did not appear willing to provide the vessels needed by the C.E.P. ${ }^{26}$ War Cabinet minutes reveal that while 
the Chief of the Imperial General Staff [C.I.G.S.], Sir William Robertson, was favourable to Portuguese pretensions, the Admiralty was not. ${ }^{27}$ This is remarkable since, from France, Haig had weighed into the debate, explaining to Derby, on 15 May, that the progress made by the Portuguese as a fighting force had been 'unduly slow'; that as a division they could only be entrusted with a very quiet sector and even then be kept under 'constant supervision'; that Portuguese officers 'regarded our army as composed mainly of amateurs from whom they had nothing to learn except a few details of trench warfare'; and that, as a result, he recommended 'that no additional troops be dispatched from Portugal beyond the requirements necessary for the maintenance of the one division now being organised in this country.'. ${ }^{28}$ Haig backed up this assessment with a summary of the C.E.P.s training, drawn up by Horne on 4 May. ${ }^{29}$ Not entirely damning, the report nevertheless stated that 'the men are sturdy, quick and willing to learn. Their relations with our men are most cordial. The root of all their inefficiency is the inexperience and incompetence of many of the officers'. Despite this report, Sir William Robertson's advice carried the day, the War Cabinet requesting Jellicoe 'to arrange with the Shipping Controller for the loan of two British transports to convey the remainder of the second Portuguese division to Brest'.

Barnardiston seems to have been of some help to the Portuguese, arguing with his interlocutors that London had acted in bad faith by breaking off the provision of shipping for the C.E.P., which ultimately made it impossible for the Portuguese to remain on the battlefield. In his diary he added,

I also thought that we were bound to do what we could to prevent the grave difficulties in which the Portuguese Government, as our oldest ally, would find itself in should we persist in our attitude.

According to Barnardiston, it was his memo to Sir William Robertson that resolved the situation. ${ }^{30}$ Norton de Matos also seems to have promised the British that the C.E.P. would not want for officers, as had been the case hitherto; this much is clear from a number of communications sent to Afonso Costa in Lisbon stating that the hurried production of officers was essential in order to secure a British agreement. ${ }^{31}$ Informed of the British decision in 16 June, Norton de Matos forcefully requested that the two ships and their escorts be kept on in Portuguese service into the future, in order to ensure the normal reinforcement of the C.E.P. ${ }^{32}$ A partially positive reply to this request was sent only on 17 July, signed by Sir Walter Langley for the Foreign Secretary, stating that the Inventor and the Bellerophon would help to transport the Second Division, after which the Inventor would be withdrawn: 'This latter vessel will provide for all the monthly reinforcements of animals and for half the monthly reinforcements of troops. It would be up to the Portuguese to make up the shortfall. ${ }^{33}$ By this stage complaints about the poor employment made of the ships had begun again, Barnardiston warning that 'failure to use them to their utmost capacity and to adhere to the required programme might cause the Admiralty to be unwilling to continue to provide shipping. ${ }^{34}$ By this stage as well, Sir Douglas Haig had again intervened in the debate on the fate of the Portuguese, reminding Derby of his letter of 15 May, quoted above, and adding that 'nothing has since occurred to me to change this position. ${ }^{35}$ Should it prove impossible to prevent this, then, in order to preserve precious equipment, including artillery, and horses, the C.E.P. should be 'organized and equipped on a defensive basis, and be allotted sufficient transport to meet the requirements of trench warfare only'.

Away from the world's attention, the First Division continued its preparation to move up to the trenches as a unit. On 19 June, after a long silence on the issue, Afonso Costa 
informed Parliament of the progress made by the C.E.P., reading out a telegram received from France. The day was coming, Costa explained, when the whole division took up its place in the front lines. Thus far a number of German raids had been carried out against Portuguese positions; these had been repulsed and morale was good. According to the prime minister, the C.E.P. had so far suffered 34 mortal casualties, including 2 officers, 185 wounded, and 15 missing in action. ${ }^{36}$ News of Portuguese forces in action was of extreme importance to the government, given the desire to use the war to convey a positive image of the country and the Republic. As far away as Honolulu, Portuguese-language newspapers celebrated the C.E.P.s baptism of fire. ${ }^{37}$

On 6 July Norton de Matos, following his return from London, addressed Parliament on the subject of the nature and the dimension of Portugal's war effort. The constant departure of troops was the cause of great worry across the country, and even in the ruling Democratic party's parliamentary group, but the Minister's words, instead of calming the situation, poured petrol on the flames. According to Norton de Matos, a decision had been taken to limit the Portuguese presence on the Western Front to an army corps, although the country could have made a greater commitment. Still, he added, an average of 4000 men would have to be sent to France every month to cover the expected losses. This came as news to Portuguese observers and meant, in essence, that in the space of a year, should the war last that long (and there was no sign that it would not), the equivalent of the C.E.P.s fighting units would have been replaced due to enemy action. Norton de Matos' speech led directly to the holding of secret sessions of parliament; these revealed concerns about the war materiel taken by the C.E.P. to France, and later replaced by British-issue weapons, ${ }^{38}$ the allegedly poor quality of the C.E.P.s medical services, and the existence of shirkers within the C.E.P. - officers who succeeded in staying well away from the battle areas, safe in the rear. ${ }^{39}$ Norton de Matos, under fire, initially agreed to a parliamentary inquiry into the 'Portuguese military services' in France ${ }^{40}$ - about which nothing was ever heard of again - but the very next day stated that the impressions he had collected while in France were very positive. As a result, the Minister of War expressed surprise at the way in which only the C.E.P.s faults were brought before the parliament, and never 'all the good things that exist in this army corps, an army corps that does not belong to the Government, but rather to the nation.'.1

On 25 June Norton de Matos, returning from London, wrote a long letter to Tamagnini, who summarized it in his memoirs:

Referring to the conference with Marshal Douglas Haig and to the latter's statement that we were very slow, he recommends that we work hard to undo the bad impression which had for so long now attached itself to us, and which many recent events had strengthened. ${ }^{42}$

Norton de Matos also urged Tamagnini to produce officers out of the soldiers and sergeants already in the C.E.P. and admitted the existence of faults in the unit:

I arrived with the sensation that not enough work was being done, that many officers were disinterested, that many of them still see the honourable mission with which they were tasked as a form of exile, as a punishment which will come to an end once the men who wanted the war, as they put it, have also disappeared [...] There is no doubt that the great majority of officers are not good; but we have a splendid minority of great officers, and, as always, it will be the minority with its admirable qualities who will triumph over the majority with its bad defects. ${ }^{43}$

Good and bad officers, dedicated and negligent officers, trustworthy and hostile officers: This was how Norton de Matos viewed the C.E.P., the unit which he had created and sent to France, entrusting it with Portugal's reputation and even its future. It is clear that within 
the C.E.P. political rivalries were intense. The Army's republican officers, in a clear minority, found themselves more isolated and exposed to their peers' hostility once in France, but relied for protection on a direct connection to the governing class in Portugal. Many such officers were to be found in the C.E.P.s Staff, led by Baptista; important in this regard as well were the parliamentary deputies at the front. These attempted to organize a dinner in honour of Norton de Matos, when the latter passed through on his way to London; Tamagnini prevented this event from going ahead. ${ }^{44}$ But it proved impossible to prevent a similar gathering during the October 1917 presidential visit to the front lines, during which Afonso Costa himself organized a lunch attended exclusively by politicians. ${ }^{45}$ Like Baptista, these parliamentarians had developed a great aversion for Tamagnini who, they thought, was simply doing the bidding of the British High Command. They asked for his replacement, Tamagnini explained in his memoirs. One of them, Barbosa de Magalhães, informed Afonso Costa on 18 September that

On one side are all the Staff officers and our friends, like Sá Cardoso and Pope, who are aware of the situation.

On the other side are only the two generals, Tamagnini and Gomes da Costa (I won't mention Simas Machado [Commander of the 2nd Division] because he counts for nothing ... suffices for me to tell you that he goes to mass every day - I'm not exaggerating, it's the truth - for you to get a sense of what he is worth).

What separated the two groups? Simply put, relations with the British:

[...] the two generals (each for his own reasons) have been carrying out the policy of the English, who pointed out to them that they were being too considerate to the Staff officers, i.e. those who stood in their way of that policy. In this way, through kindness, Tamagnini's foolishness and Gomes da Costa's ambition, the English now have the two generals, especially Tamagnini, saying amen to whatever they want, and not standing up to the resistance offered by the British to the complete organization of our C.E.P., and accepting what is, for us, a true humiliation. ${ }^{46}$

According to Tamagnini, this statement was 'simply idiotic'. But intelligence reports noted how real these divisions were, ${ }^{47}$ while other letters were written along these lines to Norton de Matos and Afonso Costa by the republican politicians now fighting in France. Sá Cardoso, a former President of the Chamber of Deputies, denounced British interference in the life of the C.E.P., notably its training. Tamagnini explained the incident behind this accusation, which illustrated vividly the clash of cultures between the two forces. Haking, while visiting the Portuguese training camp at Marthes, observed a junior officer in the Engineering Corps making a mistake during a trench-building exercise: the trench being built faced the wrong way, given the terrain. Haking intervened, showing the young officer the nature of the mistake:

And then he took him by the arm and walked half a dozen steps towards the incline. Pointing downwards, he gave some pointers in his bad French.

The camp commander felt slighted by the sudden appearance of a British general giving passing judgement before the School which he headed, and tendered his resignation. ${ }^{48}$

Asked not to repeat his visit, Haking had explained that he had not entertained 'the slightest intention of offending the young officer, rather wishing to offer him a proof of familiarity'. This seemingly innocuous incident would still be referred by Afonso Costa when he again visited the C.E.P. in November $1917 .^{49}$ 
Throughout the summer, Haking and the British Mission to the C.E.P. kept the Portuguese division under constant vigilance. On 11 July, for example, Haking passed on to the Portuguese the results of the latest inspections by XI Corps staff officers. Their biggest worry was the lack of concern displayed by the Portuguese with the state of their wire defences, often left unrepaired for more than $24 \mathrm{~h}$. Too much time elapsed before sandbag defences were repaired and made bullet-proof, and maintenance was carried out in the trench system. Some posts were left sentry-less; munitions were stored without due care, being left exposed to the rain. Litter was another problem, as well as the lack of hygiene in the kitchens. Finally, in the rear, training was insufficient. ${ }^{50}$ On 18 August Ker, wrote to Roberto Baptista after a visit to the First Division alongside Brigadier-General Studd; ${ }^{51}$ this officer had asked to pass on a few messages: the fire-steps in this part of the line required repairs; greater care was needed with British soldiers on official business in the Portuguese sector, who were not being properly fed; badly stored munitions were exposed to the elements; the cleanliness of the trenches had improved, but not that of the kitchens; the wire was in a poor state in a number of locations; and outside the front line itself disarmed soldiers could often be observed. These British concerns were not known in Portugal; all the news reproduced in the press was good. On 29 August, newspapers relayed a message by Tamagnini which detailed a failed German raid. This action had resulted in the capture of three prisoners, various clashes in no-man's land, and artillery duels; morale, the message stated, remained excellent. ${ }^{52}$

By the late summer of 1917, then, the transportation of the C.E.P.s Second Division, while still problematic, was continuing apace, and the expectation in Lisbon was that the army corps would be established with little delay and quickly take to the trenches as a whole. As we have seen, Haig tried to derail this process, on the basis of reports which reached him from below. Derby conveyed Haig's concern to Norton de Matos, who swept it aside. Barnardiston passed on Norton de Matos' reply to Derby, adding a letter of his own to the C.I.G.S. in which he noted what was clear for everyone to see - that there were 'no doubt stronger reasons for the importance attached to Lord Derby's proposal' than those mentioned in the letter. ${ }^{53}$ Barnardiston explained that while the Portuguese would never agree to the insertion of British officers in the C.E.P., it might be possible to arrange that not more than one Portuguese division should be in the line at a time, with the other in reserve, so long as they formed the one corps'. And Barnardiston pleaded for patience with the Portuguese - 'we are apt sometimes to set almost too high a standard in comparing foreign armies with our own' - given the political investment which the C.E.P. represented:

The almost inevitable results of the break-up of the army corps in France will be the upset of the Government, the loss of the services of the War Minister, an impetus to anti-war propaganda and the hostility of Portugal.

In October, President Bernardino Machado undertook a tour of the Western Front, engaging in meetings with Allied dignitaries. Some in British circles saw this as a last chance to work out a realistic deal with the Portuguese over the use of the C.E.P. ${ }^{54}$ In reality, though, as Barnardiston's diary suggests, the contacts were counterproductive. After his return from France Bernardino Machado spoke with Barnardiston on 3 November, during a diplomatic reception. A jubilant Machado had bragged that the Portuguese had made no-man's land their own, and it was now commonly referred to as 'Portuguese land'. Barnardiston despaired: 'It seems to me to be a mistake to put the butter on as thick as this'. How could Derby's proposals, he wondered, make any headway when words such as 
these were spoken before the Portuguese ${ }^{25}$ This month saw two serious blows delivered to the C.E.P., one expected, the other not. On the 11th, Barnardiston was informed that the Inventor had been removed from Portuguese service; and then, on the 27th, the Bellerophon was also taken away. ${ }^{56}$ Portugal was now left without any major transport ship capable of sending reinforcements and supplies to the C.E.P. But it was precisely in the wake of this last decision that the C.E.P. was formally constituted as a fighting army corps, and that the Second Division, its adaptation complete, joined the First in the trenches. As winter approached - the winter everyone seemed to expect would see an increase in casualties, even without German intervention - the C.E.P. faced the defence of a long sector of the front line without a steady supply of reinforcements. A week before the Bellerophon was reassigned, Ker had written a long letter to Barnardiston, bringing him up to date on the situation with the Portuguese. The First Division was improving in terms of 'discipline and morale', thanks to the efforts of Gomes da Costa - 'a tower of strength' - and Tamagnini: 'but staffs are vile, and subordinate commanders very poor'; amongst these there was not 'the faintest inclination to look after their men'. Sanitation was a constant problem, although improving; thefts from the local population and clashes with B.E.F. troops - especially the Australians ${ }^{57}$ - were another headache. A third was the lack, or ineffectiveness, of raids on German trenches. It was absolutely necessary to provide the C.E.P. with hundreds of dedicated young officers. The situation was worse in the Second Division, while political intrigue remained an enormous obstacle: this was Ker's major concern. As he put it, 'some of the human obstacles must be sacrificed if the Portuguese army is to do credit to Portugal, and if Portugal is to derive the best results from the war.'. ${ }^{5}$

It was at this time that Barnardiston was visited in Lisbon by Lieutenant Bleck, a young British officer who, because regularly resident in Lisbon, and fluent in Portuguese, had been entrusted with liaison tasks in the C.E.P.s H.Q. Bleck's testimony is extremely interesting, since he naturally desired to see the greatest possible cooperation between, and respect among, the two armies. There were others like him, the scions of British trading families long established in Portugal. Bleck's account, as transcribed by Barnardiston in his diary, was not encouraging:

Tamagnini is not supported either by his Chief of the Staff Baptista, or his divisional commanders in the way he should be. Gomes da Costa is a good soldier but seems to think he knows better than Tamagnini and is not always ready to comply with orders. Simas Machado does not work well with his corps commander. ${ }^{59}$

The picture painted of the units in the trenches was equally troubling:

There is a spirit of opposition to everything asked for by the British, \& feeling on the part of the Portuguese that we interfere. They think their organisation is better than ours \& are so conceited they will not improve themselves. Regimental officers care nothing for their men and the men have no respect for their officers and do not regard them as their leaders.

There was also little will to carry out raids against the German trenches. For the Portuguese, it seemed, the strict defence of their positions was sufficient reason to justify - and even to celebrate - their presence in France.

In his memoirs, Tamagnini noted the timeline of the army corps' establishment. By 15 August the units of the Second Division had been assembled in France, some companies having begun their initial stints in the British trenches as early as 18 June. In August they had begun to be sent up as battalions; on 5 November a Portuguese sector was formally constituted, and on 26 November the Second Division as a whole moved alongside the 
First; this step was preceded by numerous meetings with the British military authorities. ${ }^{60}$ For Tamagnini, this was a moment of supreme satisfaction, as he made clear: 'To oppose its organization would be to display lack of pride and dignity, and to betray the trust deposited in me by the Republic's government, which had appointed me.61 The creation of a Portuguese sector saw Tamagnini writing Horne, expressing the hope that 'the good feeling and friendship between the Armies of our two countries which has always existed when they have fought shoulder to shoulder for the same cause, may be renewed and intensified'. ${ }^{62}$ What no-one, on either side, seemed to reflect on, was the probable impact of the lack of reinforcements on the C.E.P. Only Barnardiston, to his credit, wrote, on 8 November when informed that the British naval transport officer hitherto stationed in Lisbon was being recalled - that 'I earnestly hope this does not indicate non-fulfilment of agreement of Portuguese Government by entire stoppage of means of transport and that conveyance of reinforcement will recommence as soon as circumstances permit. ${ }^{63}$ There was more than a touch of the absurd about this situation. While on the one hand the C.E.P.s dependence on the much larger British army had not come to an end, on the other the permanence of the whole corps in the trenches would naturally result in higher casualties, even without a full assault by the Germans opposite. On the British side, there may well have been the desire to force the Portuguese to accept the Derby plan (although there is no surviving evidence of joint action in this regard by the High Command in France and the Admiralty) by sheer force of casualties. On the Portuguese side the situation was equally complex. For Tamagnini to refuse the constitution of the army corps would have cost him his position and reputation; for the government, desirous above all else to create facts that might be used to enhance the regime's reputation, the best that might be said is that it hoped to place the Allies under greater moral pressure, using the C.E.P.s growing manpower difficulties to re-establish the maritime link between Lisbon and Brest.

\section{Notes}

1. Portugal na Primeira Guerra Mundial, Vol. 2, 196-8.

2. N.A., W.O. 106/551, N. 487, N. W. Barnardiston to Sir R. D. Whigham, 28 September 1917.

3. Portugal na Primeira Guerra Mundial, Vol. 2, 202-3. In this respect, see also Charles A. Ker's letter to Brigadier-General J. E. Edmonds, in which he explained of the Portuguese that 'their feeling against us after the Peninsular War was very acute, far more so than we ever realised until 1917. N.A., Cabinet [CAB] 45/124, C.A. Ker to J.E. Edmonds, 30 December 1931.

4. A Capital, 18 October 1917.

5. The centenary commemorations of the Portuguese Republic (2010) and of the First World War have generated a renewed interest in Portugal's participation in the conflict. A good starting point to the debates on the war's strategic dimension can be found in a special number of Nação e Defesa (n. 139) the in-house review of the Instituto de Defesa Nacional, published in 2014. Sílvia Correia has produced has delved into the cultural history of the conflict in her Entre a Morte e o Mito: Políticas da Memória da I Guerra Mundial (1918-1933). Lisbon: Temas e Debates, 2015. Correia was one two editors, along with Helena Pinto Janeiro, of a special issue of the E-Journal of Portuguese History (Vol. 11, N. 2, Winter 2013) entitled 'War Culture in the First World War: on the Portuguese Participation'. A more recent edition of this journal explored the way the conflict affected the wider lusophone world: E-Journal of Portuguese History Vol. 15, N. 1 (June 1917). An important contribution to the propaganda battle in Portugal was made by Noémia Malva Novais' Imprensa e I Guerra Mundial: Censura e Propaganda, 1914-1918. Casal de Cambra: Caleidoscópio, 2016). In terms of military history, the most important work is António José Telo and Pedro Marquês de Sousa's. O C.E.P. Os 
Militares Sacrificados pela Má Política. Lisbon: Fronteira do Caos, 2016. See also Maria José Oliveira's Prisioneiros Portugueses da Primeira Guerra Mundial: Frente Europea 1917-1918. Porto Salvo: Saída de Emergência, 2017. Other initiatives include the 'Virtual Memory' website developed by the Army's Arquivo Histórico Militar, a detailed list of all Portuguese officers, NCOs and soldiers who died fighting in the Great War (http://www.memorialvirtual.defesa.pt/ EN/Paginas/Homepage.aspx) and the Instituto de História Contemporânea's 'Memories of the First World War' website, an exercise in public history devoted to the country's participation in the conflict (http://www.portugal1914.org). Finally, numerous articles on Portugal have appeared in the 1914-1918 Online International Encyclopedia of the First World War (http:// www.1914-1918-online.net/).

6. N.A., W.O. 106/551, Sir Douglas Haig to Lord Derby, 27 August 1917.

7. N.A., W.O. 106/551, Extracts from Report by G.O.C., XI Corps, R. Haking, 13 August 1917.

8. NA., W.O. 106/551, Unsigned letter to Mackenzie (presumably General C.J. Mackenzie, commander of the 61st Division), 14 July 1917.

9. Pestana Marques, Memórias do General, clxxxii.

10. N.A., W.O. 106/551, First Army n. 1414/27 (G), O.B. 1864, General Sir Henry S. Horne to the Advanced G.H.Q., 20 August 1917.

11. In truth, the First Division was only formally constituted in April out of the troops already in France, with Gomes da Costa, hitherto in charge of a brigade, appointed its commanding officer. See N.A., W.O. 158/114, 0148/380 (S.S.2), B. B. Cubbitt to Sir Douglas Haig, 24 April 1917.

12. See, first and foremost, João de Barros interview with Afonso Costa in Atlântida Vol. 1 N. 11 (September 1916), 995-1008.

13. Telo and Sousa, O CEP, 196-8.

14. N.A., W.O. 106/545, 25700 Cipher, War Office to Barnardiston, 30 November 1916.

15. N.A., W.O. 106/545, Barnardiston to Whigham, 18 December 1916.

16. Pestana Marques, Memórias do general, lii-liii.

17. Diário da Câmara dos Deputados, 1 August 1918.

18. N.A., W.O. 158/113, 0148/380 (S.D.2), War Office, 6 March 1917.

19. N.A., W.O. 158/113, 0148/392 (S.D.2), War Office, 3 April 1917. See also Portugal na Primeira Guerra Mundial, Vol. 2, 167.

20. Portugal na Primeira Guerra Mundial, Vol. 2, 166.

21. N.A., CAB, Western and General Report No. 11. Week ending 11th April (night). Secret.

22. Oliveira Marques, O Terceiro Governo Afonso Costa, 73.

23. N.A., Diary of Sir Douglas Haig, Sunday 20 May 1917. The clashes between Baptista and the British authorities, notably the British Mission to the C.E.P., led by Charles A. Ker, can be traced in the Mission's Diary: N.A., W.O. 95/5488.

24. L.H.M.A., K.C.L., N.W. Barnardiston Papers, 3/4 Personal diary and notebook 1917-1919.

25. N.A., CAB, Minutes of a Meeting of the War Cabinet held at 10 Downing Street, S.W., on Thursday, May 31, 1917, at 11.30 AM.

26. Oliveira Marques, O Terceiro Governo Afonso Costa, 130.

27. See N.A., CAB, Minutes of a Meeting of the War Cabinet held at 10 Downing Street, S.W., on Wednesday, June 13,1917, at noon.

28. N.A., W.O. 158/114, O.B. 1864/T, Secret, Sir Douglas Haig to the Secretary, War Office, 15 May 1917.

29. N.A., W.O. 158/114, First Army No. G.S. 482, Secret and Confidential, 'Reference O.S./1864/T of 28th April, 1917', 4 May 1917.

30. L.H.M.A., K.C.L., N.W. Barnarnardiston papers, 3/4, Personal diary ...

31. Sidónio Pais would make repeated use of this and other embarrassing communications between Afonso Costa and Norton de Matos. It was included in an official note published in February 1918 and later read out in parliament. See Diário da Câmara dos Deputados, 1 August 1918.

32. Portugal na Primeira Guerra Mundial, Vol. 2, 182-4.

33. Portugal na Primeira Guerra Mundial, Vol. 2, 193-4. 
34. N.A., W.O. 106/551, N. 314, Secret and very urgent, Barnardiston to the Minister of War, 3 July 1917. See also N. 366, Barnardiston to the Minister for War, 26 July, 1917, N. 370 , Barnardiston to the Minister of War, 29 July 1917, N. 394, Barnardiston to the Minister of War, 11 August 1917, Barnardiston to H.D. Whigham, 14 August 1917, and N. 428, Barnardiston to the Minister of War, 25 August 1917.

35. W.O. 158/113, C.B./1864/B, Secret, Sir Douglas Haig to the Secretary, War Office, 9 July 1917.

36. A Capital, 19 June 1917.

37. O Luso, 30 June 1917.

38. Mira, Atas das Sessões Secretas, 53.

39. Ibid., 56.

40. Ibid., 55 .

41. Ibid., 58.

42. Pestana Marques, Memórias do General, cxxxv.

43. Ibid., cxxxvi-cxxxvii.

44. Ibid., cxxxviii.

45. Ibid.

46. Ibid., cxxxix.

47. See for example A.H.M. 1st Division, 35th Section, Box 1298, N. 57, 'Intelligence received from the CEP - France, Undated, 1917.

48. Pestana Marques, Memórias do General, cliv.

49. Ibid., clvi.

50. N.A., W.O. 106/551, Report, Brigadier General H. W. Studd to the CEP and 1st Portuguese Division HQs, 11 July 1917.

51. N.A., W.O., 105/551, Brigadier General Ker to Lieutenant-Colonel Roberto Baptista, 18 August 1917.

52. A Capital, 29 August 1917.

53. N.A., W.O. 106/551, n. 502, Barnardiston to the C.I.G.S., Very Secret and Urgent, 6 October 1917.

54. N.A., W.O. 106/551, Sir R. D. Whigham Whigham to Barnardiston, 18 October 1917.

55. L.H.M.A., K.C.L., N.W. Barnarnardiston papers, 3/4, Personal diary ...

56. N.A., W.O. 106/551, N. 513, Barnardiston to Minister of War, 11 October 1917, and telegram N. 615 (D), Foreign Office to Mr. Seeds (Lisbon), 27 October 1917. See also Portugal na Primeira Guerra Mundial, Vol. 2, 210-1.

57. Pestana Marques, Memórias do General, ccxxii.

58. N.A., W.O. 106/551, Ker to Barnardiston, Secret, 20 October 1917.

59. L.H.M.A., K.C.L., N.W. Barnarnardiston papers, 3/4, Personal diary ...

60. Pestana Marques, Memórias do General, cxl.

61. Ibid., cxli.

62. N.A., W.O. 106/551, N. 327, F. Tamagnini to Sir Henry Horne, 5 November 1917.

63. W.O. 106/551, N. 593, Barnardiston to C.I.G.S., Secret, 8 November 1917.

\section{Disclosure statement}

No potential conflict of interest was reported by the author.

\section{Bibliography}

\section{Primary sources}

A Capital (Lisbon), 1916-1917.

Arquivo Histórico Militar [A.H.M.], 1st Division, 35th Section, Box 1298.

Atlântida (Lisbon \& Rio de Janeiro), 1916.

Diário da Câmara dos Deputados (Lisbon), 1916-1917.

Liddell Hart Centre for Military Archives, King’s College London, N. W. Barnardiston papers. 
de Oliveira Marques, A. H., ed. O Terceiro Governo Afonso Costa: Actas dos Conselhos de Ministros. Lisbon: Livros Horizonte, 1977.

O Luso (Honolulu), 1917-1918.

Marques, Isabel Pestana, ed. Memórias do general 1915-1919: “Os meus três comandos” de Fernando Tamagnini. Viseu: Fundação Mariana Seixas, 2004.

Mira, Ana, ed. Atas das sessões secretas da Câmara dos Deputados e do Senado da República sobre a participação de Portugal na I Grande Guerra. Lisbon: Assembleia da República/Afrontamento, 2002. National Archives [N.A.], London, Cabinet Papers [CAB], 124.

N.A., Foreign Office [F.O.] 371/2759, 371/2761.

N.A., Treasury [T] 12,108/42,875.

N.A. War Office [W.O.] 95/5488, 106/545, 106/551, 158/113, 158/114, and Diary of Sir Douglas Haig. Portugal na Primeira Guerra Mundial (1914-1918). 2 vols. Lisbon: Ministério dos Negócios Estrangeiros, 1997.

\section{Secondary sources}

de Fraga, Luís Alves. Guerra e marginalidade: O comportamento das tropas portuguesas em França, 1917-1918. Lisbon: Prefácio, 2003.

de Meneses, Filipe Ribeiro. Portugal 1914-1926: From the First World War to Military Dictatorship. Bristol: HiPLA Monographs, 2004.

Telo, António José, and Pedro Marquês de Sousa. O C.E.P. Os Militares Sacrificados pela Má Política. Lisbon: Fronteira do Caos, 2016. 